\title{
STATISTICAL ANALYSIS OF CROSSBREEDING EXPERIMENTS IN PIGS
}

\section{I:. Bruxs. - Institut of Animal Breeding and Genetics Göttingen, BRD.}

Three alternative procedures for analyzing crossbreeding experiments in pigs — an indirect method, least squares, and maximum likelihood - were compared as applied to two years test results from a German Federal Crossbreeding Experiment.

The results are :

I. Estimates of error mean squares obtained in the least squares analysis were atout $5^{-}$ $15 \mathrm{p}$. Ioo smaller than those obtained in the indirect analysis.

2. Standard errors of estimates of cross effects obtained from direct procedures (LS, ML) were slightly greater than those from the indirect analysis.

3. Correlations between rankings of crosses in two years were slightly higher for carcass characteristics when least squares or maximum likelihood constants were used instead of constants from the indirect method but this was not true for days fattened.

4. Correlations between rankings of crosses under alternative procedures within each year are rather high $(r \geqslant .90)$ for carcass traits, but not for fattening traits.

5. Least squares and minimum likelihood methods rank crosses with similar precision.

6. In the future comparisons of crosses in pigs should be made under a variety of practical management conditions and designed such that genotype environment interactions can be eliminated statistically.

\section{STATISTICAL EFFICIENCY IN BULI PROGENY TESTING FOR CALVING DIFFICULTY}

\begin{abstract}
G. A. T. MahoN and E. P. Cunningham. - Dublin University and the Agricultural Institute, Dublin.
\end{abstract}

The Poisson distribution was used to examine the precision attainable in bull progeny testing for traits like calving difficulty as the following parameters were varied : $p_{0}$ the basic incidence level in the population, $n$, the progeny group size, and $\alpha$ and $\beta$ the probabilities of two kinds of erroneous conclusion. The results showed that, in all circumstances, a group size of 250-300 progeny gave a good compromise between cost and precision.

There was little to choose between testing based on calvings in heifers and in cows. As the basic frequency increases, more progeny are required for a given degree of precision. Thus testing is more expensive in breeds with high rates of difficult calving than in those with low rates.

\section{ESTIMATING CROSSBREEDING PARAMETERS WHEN TWO BREEDS UTILIZE COMMON BREEDING ANIMALS}

\section{E. Fimland. - Department of Animal Genetics and Breeding, Agricultural University of Norway,

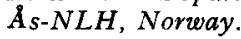

Samen from elite-bulls of Swedish Red (SRB) and of Norwegian Red (NRF) breeds has for some times been exchanged. The elite-bulls are the sires of the next generation of young bulls. The young bulls used within one of these cattle populations would therefore include both full and half bloods individuals. A batch of these young bulls are progeny tested in a regulary way.

The sire evaluation method used within both breeding populations is assumed to eliminate non-genetic factors properly. By combining linear functions of the sire proves from both populations estimates of crossbreeding parameters of interest can be obtained. The crossbreeding parameters of interest can be given as follows :

I. $\mathrm{D}=\mathrm{G}_{\mathbf{S}}-\mathrm{G}_{\mathbf{N}}$ is the difference in breeding values between the Swedish and the Norwegian Red elite bulls (i.e. the next generation of young bulls).

2. $\mathrm{H}$ is the heterotic effect caused by crossing these two breeds. 
The proves of these young bulls tested within one of these breeding populations have expectations that are linear functions of $G_{S}, G_{N}$ and $H$. The first letter of the subscript denotes the origin of the sire of the young bull and the second letter of the subscript denotes the breed of the test population.

The following relations can be obtained :

$$
\begin{aligned}
& \mathrm{A}=\overline{\mathrm{I}}_{1 / 2 \mathrm{SN}}-\overline{\mathrm{I}}_{\mathrm{NN}}=1 / 2 \mathrm{D}+\mathrm{H} \\
& \mathrm{B}=\overline{\mathrm{I}}_{1 / 2 \mathrm{NS}}-\overline{\mathrm{I}}_{\mathrm{SS}}=-1 / 2 \mathrm{D}+\mathrm{H}
\end{aligned}
$$

where $\bar{l}$ attached with subscripts are mean performance of different breed groups tested in different population.

Thus, it follows that :

$$
\begin{aligned}
& H=1 / 2(A+B) \\
& D=A-B
\end{aligned}
$$

Henceforth, the crossbreeding parameters of interest can be estimated by combining the proves of the young bulls used in these two cooperative breeding populations.

\section{Communications libres}

\section{THE INFLUENCE OF ERRORS IN GENETIC COVARIANCES ON THE EFFICIENCY OF A COW INDEX}

\section{A. ZaRNecki. - Academy of Agriculture, Department of Genetics and Animal Breeding, 30-059 Cracow, Poland.}

The purpose of this study was to examine the influence of errors in estimates of genetic covariances on the efficiency of a cow selection index. The indexes utilised information obtained from the cow's own three records, or these three records together with the records of groups of paternal half-sisters. The efficiency was studied by correlating the estimates with indexes based on genetic parameters estimated with errors.

The efficiency of indexes calculated from genetic covariances estimated with an error decreased as the error itself increased. Large losses of efficiency, however, only occurred with very serious under- and over-estimations. Moderate errors were found not to affect efficiency substantially particularly when the index containcd large amounts of information.

\section{EIN VERGLEICH DER “ CUMULATIVE DIFFERENCE " METHODE MIT DER “ SIRE COMPARISON " METHODE}

\section{DEMPFLE. - Institut für Tierzucht der Technischen Universität München, D-805 Freising - Weihenstephan.}

Von Lenz, Miller und Henderson (ig69) wurde die Sire comparison Methode und von Bar-ANan und SaChs die cumulative Differenzmethode zur Zuchtwertschätzung der Bullen vorgeschlagen, wenn ein genetischer Trend oder sonstige systematische genetische Unterschiede in der Population vorhanden sind. Die Sire comparison Methode schätzt die Zuchtwerte mit Hilfe von Blup (Best linear unbiased prediction). Die cumulative Differenzmethode ist eine Weiterentwicklung der Contemporary comparison Methode, wobei das genetische Niveau der Zeitgefährtinnen berücksichtigt wird. An einem einfachen Beispiel wurde gezeigt, dass die cumulative Differenzmethode den Einfluss des genetischen Niveaus der Vergleichstiere nicht voll ausschaltet. Der geschätzte Zuchtwert eines Tieres hängt nach wie vor davon ab, ob die Zeitge- 